\title{
„NA BRZEGU NIEZNANEJ OTCHŁANI”. Z ANTROPOLOGII ZYGMUNTA KRASIŃSKIEGO
}

\author{
AGNIESZKA ZIOŁOWICZ*
}

Schyłkowe lata życia Zygmunta Krasińskiego to z rzadka interpretowana faza biografii poety. Są ku temu powody. Krasiński, bardzo już schorowany, nie podejmuje wtedy szerzej zakrojonej aktywności literackiej i intelektualnej. Nieustanne kuracje, ograniczone kontakty towarzyskie, rodzina, lektury, pojedyncze wiersze, acz nie bez znaczenia, przyjacielska korespondencja - oto, co stanowi w tym okresie treść jego życia. Biografowie, odwołując się do autorefleksji poety, zawsze przecież głęboko samoświadomego, piszą o ówczesnym ,stanie irytacji nerwów" i poczuciu klęski, zarówno osobistej jak i politycznej, w sytuacji, gdy: „Wszystko się łamie - rozstraja - rozrywa"1, ale zarazem dostrzegają siłę przekonań moralnych i historiozoficznych racji, mającą u swych podstaw niezłomną wiarę w Opatrzność, która pozwala mu do końca przemawiać głosem proroka nadziei ${ }^{2}$, coraz trudniej osiągalnej nadziei, dodajmy.

Widziany na tym tle rok 1857, a zwłaszcza jego pierwsza połowa, wyróżnia wzmożona praca myśli, napięcie emocjonalne, konsolidacja sił duchowych poety. Przyczyna ma zrazu charakter zewnętrzny - z początkiem roku przybywa bowiem do Paryża mediumista Daniel Douglas Hume, nad którym protektorat roztoczył hrabia Aleksander Branicki, rodzony brat żony Zygmunta Krasińskiego. Hume - Szkot, rodem z Wysp Orknejskich, rozsławiony już swymi występami w Ameryce i powiązaną z egzorcyzmami audiencją u papieża Piusa IX, uznawany za Caligostra epoki romantyzmu - szybko podbija stolicę Francji. O skali sukcesu mogą świadczyć liczne doniesienia prasowe, relacjonujące przebieg seansów

* Agnieszka Ziołowicz - dr hab., prof. UJ, Wydział Polonistyki UJ.

1 Jest to fraza z wiersza I stowik tylko po święty Wit śpiewa (zob. Z. Kra si ń s ki, Dzieła literackie, wybrał i oprac. P. Hertz, t. I, Warszawa 1973, s. 119), pochodzącego najprawdopodobniej z roku 1852. Warto przypomnieć, że swą twórczość liryczną Krasiński zamkną takimi utworami, jak: W dzień świętej Elżbiety (1856), Do mojej Elizy (1857), Cokolwiek będzie, cokolwiek się stanie... (1857), W twoim ze śmierci ku życiu odrodzie... (1858), w których refleksja osobista splata się ściśle z historiozoficzną.

2 Zob. Z. Sudolski, Krasiński. Opowieść biograficzna, Warszawa 1997, s. 481-535. Autor tej monografii rozdziały poświęcone ostatnim latom życia Krasińskiego tytułuje znacząco: „«W stanie irytacji nerwów» - przebłyski nadziei”, „Sielanka i tragedia złotopotocka”, „U kresu - świadomość klęski i siła przekonań”. 
z jego udziałem, które, co dla rozgłosu nie bez znaczenia, nie ominęły również dworu cesarskiego, odwiedzanego przez Hume'a bodaj czterokrotnie ${ }^{3}$.

Francja stwarzała wyjątkowo dogodne warunki do prezentowania magnetycznych eksperymentów. Trudno w tym miejscu o szczegółowe uzasadnienie powyższego sądu, dość powiedzieć, że właśnie we Francji osiadł w roku 1778 twórca magnetyzmu Franz Anton Mesmer, że to w Paryżu prowadził swoją działalność, przysparzającą popularności i jego terapii, i jego doktrynie w całej Europie. Niemałą rolę w propagowaniu idei magnetycznych odegrali uczniowie i kontynuatorzy dzieła Mesmera, nawet ci różniący się w swych poglądach z mistrzem, jak markiz Armand de Chastanet de Puységur, Joseph Deleuze, Charles de Villers czy ksiądz Jose Custodio de Faria. Rozpowszechniały idee magnetyzmu również towarzystwa harmoniczne, powoływane do życia najpierw we Francji, potem w Niemczech, Rosji, a także w Polsce, w celu studiów nad magnetyzmem i rozwijania magnetycznych praktyk. Czynnikiem utrwalającym zainteresowanie poglądami Mesmera i jego kontynuatorów były też publikacje prac przedstawicieli i komentatorów, a w końcu i historyków doktryny, bardzo liczne zwłaszcza we Francji i w Niemczech. (Niektóre z nich znane były Krasińskiemu ${ }^{4}$ ). O magnetyzmie nie pozwalały wreszcie zapomnieć wciąż odradzające się spory o naukowy status zjawiska, w których prym wiedli lekarze, ale do których włączali się fizycy, filozofowie, reprezentanci różnych wyznań religijnych, raz przekonani o naukowości i wyjątkowej randze poznawczej i terapeutycznej magnetyzmu, a kiedy indziej sytuujący go w sferze okultyzmu, pozbawionego wartości naukowej i pozostającego w sprzeczności z nauczaniem Kościoła ${ }^{5}$. Tak oto magnetyzm, jedno z ubocznych zjawisk towarzyszących początkom romantyzmu ${ }^{6}$, znalazł się

${ }^{3}$ Szerzej o seansach na dworze cesarskim, przebiegających w obecności cesarza Napoleona III i cesarzowej Eugenii, pisze Stanisław Wasylewski, zob. te g o ż, Pod urokiem zaświatów, Kraków 1958, s. 71-92. Wasylewski odnotowuje ważniejsze źródła zawierające informacje o osobie Hume'a: M. Perty, Die mystischen Erscheinungen der menschlichen Natur, Leipzig 1872, t. II, s. 40; W. S chne id e r, Der neuere Geisterglaube, Paderborn 1913, s. 136, 160, 418.

${ }^{4} \mathrm{Z}$ pewnością czytał książkę niemieckiego profesora medycyny, znanego z magnetycznych kuracji, Josepha Ennemosera Der Magnetismus im Verhaltnis zur Natur und Religion (1842), co poświadcza korespondencja poety. Warto nadmienić, że w obiegu czytelniczym znajdowały się wtedy również pisma samego Mesmera; ich wznowienie ukazało się w roku 1826.

${ }^{5}$ Szczegółowe relacje na temat europejskiej recepcji magnetyzmu zawierają prace: L. Ch erto k, R. de S a u s u re, Rewolucja psychoterapeutyczna. Od Mesmera do Freuda, Warszawa 1988; L. Chert ok, Hipnoza i sugestia, przeł. B. Kupis, Warszawa 1993; B. Płonka-S y ro ka, Mesmeryzm. Od astrologii do bioenergoterapii, wyd. 3 poprawione i uzupełnione, Wrocław 2007. Ta sama autorka zajmowała się także mesmeryzmem w kontekście dziewiętnastowiecznych doktryn medycznych, zob. tej że, Doktryny medyczne nurtu hermetycznego - struktura, geneza, uwarunkowania recepcji w społeczności naukowej, „Medycyna Nowożytna” 1992, s. 7-38; te jże, Niemiecka medycyna romantyczna, Wrocław 2007. Z kolei obyczajowa strona magnetyzmu stała się przedmiotem interpretacji w książce: J. M. Ry m ki ew i c z, Baket, Londyn 1989.

${ }^{6}$ Trzeba zaznaczyć, iż magnetyzm towarzyszył również początkom romantyzmu w Polsce. Nasilenie zainteresowań mesmeryzmem przypada na lata 1815-1818, a dotyczy zwłaszcza Wilna, a potem także Warszawy. W wileńskim gronie propagatorów magnetyzmu czołowe role odegrali 
w centrum sporów światopoglądowych epoki i pozycję tę, sam podlegając ewolucji, zachował przez cały wiek XIX.

Właśnie z tego względu, jako ważki i nadal żywy argument w dyspucie światopoglądowej, magnetyczne eksperymenty Hume’a stały się obiektem zaciekawienia ze strony jego współczesnych. Znaleźli się wśród nich nie tylko wspomniany wcześniej papież i reprezentanci francuskiego dworu, ale także luminarze nauki - wiadomo, iż fenomen Hume’a był przedmiotem obserwacji i studiów angielskich uczonych (Crookes, Lindsay, Wallace) oraz akademików petersburskich. Trudno zatem dziwić się, że do tego grona dołączył Zygmunt Krasiński. O stopniu jego zainteresowania osobą mediumisty świadczy seria listów, w których z niezwykłym ożywieniem poeta relacjonuje i komentuje wydarzenia, jakich on sam, a także jego bliscy byli świadkami. (Notabene Hume przyjmowany był w domu zarówno przez Aleksandra Branickiego, jak i przez samego Krasińskiego w jego paryskim mieszkaniu przy rue Dauphot 8, co dziennik „Indépendance” odnotowywał nie bez zjadliwości: „Le comte K. a fait de son salon l'auberge de Satan"7 ). Wspomniane listy, skierowane do Hieronima Kajsiewicza, Bronisława Trentowskiego, Józefa Korzeniowskiego, Stanisława Egberta Koźmiana i Adama Sołtana, wespół z rozprawą zatytułowaną przez wydawcę Jana Czubka Magnetycznośc ${ }^{8}$, która w warstwie problemowej, a w większości i leksykalnej, pokrywa się z listem do Kajsiewicza, pozwalają na prześledzenie sposobu rozumienia przez poetę fenomenu magnetyzera. Dają powody, by mówić o fluktuacji postawy i poglądów ich autora na temat przebiegu seansów: od uważnej obserwacji, przez niedającą się ukryć fascynację, tak bardzo niepokojącą przyjaciół poety, po pewien rodzaj sceptycyzmu, powiązanego z dociekaniem jakości prezentowanych objawień, który nie przeradza się jednak w kwestionowanie ich autentyczności; wątpliwości dotyczą źródła: ich pochodzenia ze sfery dobra lub zła.

W liście do Sołtana (z 2 marca) Krasiński, najwyraźniej zaintrygowany, określa charakter działań Hume’a: „Hume, medium amerykańskie, przez Aleks[andra] Bran[ickie]go utrzymywane, niesłychanych dokazuje cudowności. Dzwonki same chodzą po pokojach i wabią się dźwiękiem serc swych poruszonych niewi-

profesor uniwersytecki Józef Frank, uczony amator Ignacy Emanuel Lachnicki, założyciel „Pamiętnika Magnetycznego Wileńskiego", w którym publikowane były prace klasyków mesmeryzmu, oraz Jan Baudouin de Courtenay, podający się za ucznia Mesmera założyciel Towarzystwa Harmonicznego i autor pracy Rzut oka na mesmeryzm czyli systemat wzajemnych wpływów $i$ skutków, objaśniajq̨cy teorię i praktykę magnetyzmu zwierzęcego (Warszawa 1820). Zob. B. Płon k aSy roka, Mesmeryzm..., dz. cyt., s. 167-201 (rozdz. „Mesmeryzm po polsku”).

7 Cyt. [za:] S. Was yle w ski, dz. cyt., s. 86.

${ }^{8}$ Zob. Z. K rasiń s ki, Magnetyczność [w:] Pisma Zygmunta Krasińskiego, oprac. J. Czubek, t. VII: Pisma filozoficzne i polityczne, Kraków-Warszawa 1912, s. 161-165. Z. Sudolski opublikował ten fragment pośród listów Krasińskiego do nieznanych adresatów jako poszerzoną wersję części listu do Kajsiewicza, zob. Z. K ra si ń s ki, Listy do różnych adresatów, zebrał, oprac. i wstępem poprzedził Z. Sudolski, Warszawa 1991, t. II, s. 411-414. 
dzialnymi siły. Chustki latają po powietrzu i zawiązują się na węzły same. Ręce pod stolikiem jakieś nieludzkie, zaświatowe wstają i dotykają osób przy stoliku siedzących, a niektórym widomie się objawiają. Cesarz i cesarzowa je widziały. Pani D[elfina] pozawczoraj taką rękę czuła we własnej i ledwo nie zemdlała"9. Podobną charakterystykę, choć emocjonalnie bardziej nacechowaną, znajdziemy w liście do Kajsiewicza (z 11 marca): „Hume, medium szkockie czy amerykańskie szwagra mego, całe to miasto zapełnia rozgłosem dziwów pokazywanych co wieczora tu i ówdzie [...]. Cesarz i cesarzowa oglądali na oczy podnoszące się i wiszące w powietrzu stoły i ręce dotkliwe, to świecące, to bezprzejrzyste, z powietrznego znikomego płynu ukształtowane, spod stolika się wynurzające i rozmaicie działające, bo dzwonią dzwonkami, grywają na akordeonach, zawiązują chustki na węzły, ściskają dłonie przytomnych, czasem na fortepianach grają i gdy wyniesiesz świece z pokoju oglądasz jak najwyraźniej ramię i rękę ze światła bladego po klawiszach się przemykającą [...]. Jam dotąd tylko stoły zrywające się z ziemi, ale wnet też i opadające, i krzesła same kilka kroków po pokoju ubiegające się widział. Lecz w ręku Elizy słyszałem (pod stołem, w ciemni) grający akordeon i przytomny byłem, kiedy jej siła jakaś (zawsze pod stołem) dzwonki z rąk wyrywała i nazad wtykała je do rąk"10. List do Trentowskiego wnosi do opisu istotne novum - informację o poznawczym dystansie i nieskrywanej podejrzliwości autora w stosunku do natury oglądanych zjawisk: „Bardzo mię zatrudnia teraz tu będące me diu m amerykańskie, pełne magnetycznej siły, sprawiającej zjawiska najdziwniejsze w oddali od obrębów jego organizmu i wchodzącej nawet $\mathrm{w}$ zetknięcie $\mathrm{z}$ duchami [...]. O tym za widzeniem całą Ci moją teorią opowiem. Tworzy się ona we mnie w miarę, jak posuwam się w oglądaniu tych zjawisk i nachylam się ku wierze, że to psoty i omamienia złych duchów"11.

W końcu w liście do Koźmiana (26 kwietnia) Krasiński dochodzi do konkluzji: ,ja jeden śród koła zajętych Mediumem, zda mi się, zachowywałem rozwagę i przytomność. Śledziłem go, badałem, podejrzywałem wszystko w nim, krok w krok stąpałem za nim, zawszem się miał k'niemu obronnie i uorężnionym duchem walczyłem przeciwko niemu, ostrzegając drugich, rzucających się w otchłań tych zjawisk lub staczających się w nią, a obałamuconych i upojonych. Przekonałem się, że kształt zjawisk, czyli objawów tych, które istotnie z zaświata pochodzą, lichy - charakter samego pośrednika lichy - wpływ wywarty na widzów lichy. Stąd jaki wniosek o pierwiastku, rządzącym tymi zjawiskami? Wreście Medium wykluczył mię ze swoich posiedzeń, z grona wiernych swych mię wygnał, unikał mię, wystrzegał mnie, oświadczając, że mu przeszkadzam myślą

${ }^{9}$ Z. Krasińs ki, Listy do Adama Sołtana, oprac. i wstępem poprzedził Z. Sudolski, Warszawa 1970, s. 637.

${ }^{10}$ Z. K rasin s k i, Listy do różnych adresatów, dz. cyt., t. II, s. 268.

${ }^{11}$ Z. Kr as iń sk i, Listy do Cieszkowskiego, Jaroszyńskiego, Trentowskiego, oprac. i wstępem poprzedził Z. Sudolski, Warszawa 1988, t. II, s. 254. 
ciągłą, iż złe duchy ukryte pod tym wszystkim. Widzisz więc, że nie tylko pod wpływ jego się nie oddałem, alem wystąpił przeciwko niemu do walki"12.

W cytowanych fragmentach korespondencji, a także w tych, których z oczywistych względów cytować nie mogę, uwidocznia się niezwykła ranga wielokrotnie obserwowanego przez poetę zjawiska. Krasiński, najwyraźniej wewnętrznie poruszony, wytrącony z pewności swych przekonań, próbuje racjonalnie pojąć to, co niepojęte: „Ogromnie zimno mam się do tych wszystkich zjawisk. Czuję się jakby na brzegu nieznanej otchłani - pisze - skupiam całą moc spokoju i rozsądku, i uwagi, i rozwagi, by dociec, jakiej ta siła istotnie natury"13. W rezultacie podjętych badań sytuuje magnetyczne eksperymenty Hume'a w różnych kontekstach problemowych: zarówno w kręgu własnych duchowych zmagań (uorężnionym duchem stacza przecież walkę o znamionach psychomachii), jak i dociekań rozumowych, układających się w teoretyczny wywód, wzmiankowany w liście do Trentowskiego, a zrealizowany w liście do Kajsiewicza i rozprawce Magnetyczność. Przekonany o „ogromnej, nadzwyczajnej, wyglądającej na cudowną" sile Hume'a (zarazem zastrzegając, że ,c u d o wn a a cu d to wcale inne wyobrażenia" ${ }^{14}$ ), z przenikliwością dostrzega w jego aktywności również przejawy choroby ciała i ducha, a także oznaki kuglarstwa, zaspokajające oczekiwania publiczności żądnej igrzysk, świadczące o niejakim wyrachowaniu mediumisty, które wynika ze znajomości ludzkich charakterów, przede wszystkim niewieścich, oraz z „wielkiej przebiegłości moralnej” ${ }^{15}$. Pomimo tej sprzeczności w ocenie, której Krasiński jest świadom, Hume okazuje się najistotniejszym wówczas dla myśli poety punktem odniesienia, urasta do roli czynnika przesądzającego o żywotnych dlań kwestiach egzystencjalnych i intelektualnych. Staje się żywym świadkiem, probierzem, argumentem.

Odpowiadając na ironicznie traktujący Hume'a list Józefa Korzeniowskiego ${ }^{16}$, Krasiński uzna zatem mediumistę za objawiciela tajemnicy życia, jedynej i niezmiennej, sięgającej korzeniami aktu stworzenia świata, a mającej w centrum

${ }^{12}$ Z. Kra sińs k i, Listy do Koźmianów, oprac. i wstępem poprzedził Z. Sudolski, Warszawa 1977, s. 448.

${ }^{13}$ Z. Krasińs ki, Listy do różnych adresatów, dz. cyt., t. II, s. 268 (List do H. Kajsiewicza z 11 marca 1857).

14 Tamże.

15 Tamże, s. 269.

${ }^{16}$ List ten jest wyrazem jednoznacznie krytycznego stosunku Korzeniowskiego do działań Hume'a. Oprócz żartobliwego wiersza, skierowanego do Krasińskiego, znajdujemy w nim słowa pełne zaniepokojenia i zdroworozsądkowego sceptycyzmu: „,czyż to prawda, żeś uwierzył i przeważnym swym zdaniem potwierdzasz to, co nie ma zasady? Cóż by się stało z biednym światem materialnym, gdyby nie ulegał prawom pewnym i niezmiennym? Cóż by powiedział Archimedes, że mu wyruszają ziemię z posad bez drąga, a co gorsza, bez punktu podpory? Cuda są tylko w świecie ducha. Wyzdrowiej Ty i pisz, a wtedy i ja powiem: »chodźcie i patrzcie, lasy słuchają i skały idą!«"; zob. Z. K ras iń s ki, Listy do różnych adresatów, dz. cyt., t. II, s. 502 (Aneks I. Listy do Zygmunta Krasińskiego). 
człowieka: „Praw niezmiennych nigdzie nie ma, jedno w sumieniu i w sferze sprawiedliwości duchowej - zresztą nigdzie, bo wszędzie jest życie, a życie jest zmiennością. Tajemnica tylko życia niezmienną pozostaje i jedyną - a znamyż ją? a wiemyż, czy to zgadza się z nią lub nie? Iżaliśmy byli, kiedy Pan świat stwarzał - przy stworzeniu?" 17 Magnetyzm - jak dowodzi w liście do Kajsiewicza - uchyla nam rąbka tej tajemnicy, umożliwiając wyjaśnienie wielu odwiecznych problemów antropologicznych. Przede wszystkim rozwiązany zostaje dzięki magnetyzmowi problem paralelizmu psychofizycznego. Krasiński jest przekonany, że w człowieku, złożonym z duszy i z ciała, „musi być coś trzeciego, służącego za pośredniczy związek między nimi, za klamrę duszy, spiętej do ciała, coś mającego pewne przymioty ciała i zarazem pewne idealności”" ${ }^{18}$. To „coś” to płyn magnetyczny, nazywany przez niego x, a przybierający w naturze formy ,,jeszcze cielesne, a już prawie nie", dający się zaobserwować w postaci światła, cieplika, elektryczności. Myśl o płynie magnetycznym rozlanym w świecie i jednocześnie obecnym w człowieku zbliża Krasińskiego do tradycyjnych idei magnetycznych, do pierwotnej wersji doktryny, zakładającej istnienie fluidu magnetycznego przenikającego całe stworzenie i tym samym nadającego mu jedność, wewnętrzną harmonię. Do idei tych nawiązywała - jak wiadomo - wczesnoromantyczna filozofia przyrody, traktująca człowieka jako mikrokosmos, w którym odzwierciedla się uniwersum, poszukująca w najgłębszych pokładach ludzkiego Ja niepoznawalnej inaczej istoty wszechświata.

Dlatego magnetyzm może być w teoretycznych rozważaniach Krasińskiego również kluczem do zrozumienia życia wewnętrznego człowieka, życia duszy i funkcjonowania ludzkiego umysłu z jego zdolnościami poznawczymi i kreacyjnymi. Siły magnetyczne spajają bowiem różne aspekty istnienia i aktywności podmiotu. Integrują życie na jawie z życiem we śnie, wiążą słoneczną i księżycową stronę ducha ludzkiego; odpowiadają za współdziałanie w człowieku myśli, wyobraźni i woli. Podstawowy mechanizm życia umysłu polega wedle poety na tym, że „myśl czysta, oderwana”, niewyartykułowana „musi przemienić się w kształt i obraz"19. Tak w interpretacji Krasińskiego przedstawia się zasada snu, rozumowania, działania i twórczości artystycznej. Należy ona do istoty relacji zachodzących między duszą a ciałem, realizowana jest w ramach dwukierunkowej komunikacji między nimi, w której niezbywalny czynnik pośredniczący stanowi magnetyczność. Istnieją jednak pewne różnice w funkcjonowaniu umysłu na jawie i we śnie. Na jawie myśl czysta, dążąc „ku kształtowi i obrazowaniu się" znajduje wyraz przede wszystkim w dźwięku słowa, zaś we śnie ekspresja ma charakter głównie obrazowy. Ponadto na jawie czynna jest ludzka wola, nieaktywna w stanie śnienia. To pod kierunkiem woli na jawie myśl znajduje

\footnotetext{
17 Tamże, t. I, s. 505.

18 Tamże, t. II, s. 411.

${ }_{19}$ Z. K rasińs ki, Listy do różnych adresatów, dz. cyt., t. II, s. 411.
} 
artykulację w formie rozumowania i czynu. Jedynie w twórczości artystycznej dochodzi do zatarcia zróżnicowań: „Dopiero w sztukach wola każe myśli tak samo rozumować i służyć czynom, jak na jawie! i zarazem dozwala jej, jak we snach, przeobrażać się w obraz i postać. W sztukach jest już pewne, ale normalne zawsze, bo pod woli kierunkiem wciąż, połączenie stanu jawu ze stanem snu"20.

Czyniąc siły magnetyczne pośrednikiem między duszą a ciałem, Krasiński dostrzega ich oddziaływanie także w różnych dziedzinach zewnętrznej aktywności człowieka, przede wszystkim w sferze „,̇ywota społecznego” - na poziomie relacji interpersonalnych są one konstytutywnym elementem więzi, zwłaszcza miłosnej, na poziomie życia zbiorowego konstytuują wspólnotę wokół polityków, mówców, bohaterów ${ }^{21}$. Nawet świętość jest przez poetę interpretowana w perspektywie magnetyzmu jako stan, w którym siła x podlega procesowi idealizacji, aż wreszcie dochodzi do takiego stopnia jej odcieleśnienia, że ,może duszy uświęconej służyć niejako za zwierciadło pośredniczące, w którym odbija się chwała i działanie duchów niebieskich"22.

Z drugiej strony, Krasiński zna również negatywne aspekty magnetyczności. Jak dowodzi, w stanie choroby naruszającej relację duszy i ciała siły magnetyczne uwalniają się w sposób niekontrolowany, co zagraża nie tylko choremu, ale i jego otoczeniu, które z łatwością może wówczas popaść w stan atrofii woli: omamienia lub anarchii. Może to również prowadzić do intencjonalnie złego po-

${ }^{20}$ Tamże, s. 412. W innym miejscu czytamy: „W snach naszych ukryte są ogromne potęgi elementarne nas samych. Nie na powierzchni duszy, ale w samej głębi serca rodzą się sny. Cóż to za potęga stworzyć świat kolorów bez światła, świat głosu bez dźwięków, świat zmysłowy cały bez zmysłów, poezję bez natchnienia, bez rozwagi, bez świadomości! To natura nasza, która bez dołożenia się woli naszej sama gra i śpiewa, i prorokuje, i poemata pisze. [...] W śnie - żywa natura wynajduje, tworzy, maluje wolno i bez granic! Sen każdy zawiera w sobie proroctwo, że kiedyś materia zupełnie się podniesie do godności ducha" (Z. Krasiński, Listy do Delfiny Potockiej, oprac. i wstępem poprzedził Z. Sudolski, Warszawa 1975, t. I, s. 135-136). Krasiński co prawda nie posługuje się w swych wywodach terminem ,nieświadomość”, ale niewątpliwie problematyki nieświadomości dotyka. Magnetyzm ujawniał bowiem możliwość głębokiej regresji człowieka do stanu przedwerbalnego, o czym wiedział już Mesmer, a także jego następcy, opisujący to zjawisko coraz precyzyjniej. O roli doktryny i praktyki magnetycznej w odkrywaniu i poznawaniu sfery nieświadomości piszą wszyscy wzmiankowani powyżej badacze magnetyzmu, zaś z punktu widzenia historii psychologii czyni to Bartłomiej Dobroczyński, zob. te go ż, Idea nieświadomości w polskiej myśli psychologicznej przed Freudem, Kraków 2005.

${ }^{21}$ Związki magnetyzmu i stosunków interpersonalnych (przede wszystkim relacja magnetyzer - osoba magnetyzowana) były przedmiotem obserwacji i refleksji samych magnetyzerów, coraz bardziej dzięki temu świadomych psychicznego oddziaływania międzyludzkiego, a zwłaszcza znaczenia uczuć dla przebiegu ich praktyki medycznej, a także w ogóle dla społecznego funkcjonowania człowieka. Kwestia ta rzutowała również na naukowe i kościelne oceny magnetyzmu, nierzadko uznawanego za zjawisko niemoralne, bo odwołujące się do uczuciowej, czy wręcz erotycznej strony życia pacjentów. Wniosek tajnej komisji, powołanej przez Ludwika XVI do zbadania działalności Mesmera, brzmiał: „Leczenie magnetyczne może być jedynie zagrożeniem dla obyczajności”. Zob. więcej: L. Che rtok, R. de S a u s s u re, dz. cyt., s. 26-32.

${ }^{22}$ Z. Kr a sińs k i, Listy do różnych adresatów, dz. cyt., t. II, s. 412. 
sługiwania się magnetyzmem - z ciekawości, pychy, obłudy, potrzeby dominacji nad innymi, pragnienia rozkoszy etc., co z kolei stwarza dogodne warunki nie tylko do manipulowania człowiekiem, lecz i do wcielania się złych duchów. To dlatego tak ważna okazuje się dla poety odpowiedź na pytanie - jego zdaniem jedno z najważniejszych pytań wieku - o jakość duchów, do których dostęp dają mediumiści. „A jeśli to same złe duchy - zastanawia się - tak mnogo i publicznie, tak demokratycznie, że tak powiem, wszędzie, za lada stolika dotknięciem przybiegające i obcujące z rodem ludzkim, z którym dawniej tylko wyjątkowo i za pośrednictwem piekielnych obrzędów obcowały, cóż to za straszny znak?”23 Konkluzja jest jednoznaczna - wzmożone kontakty z duchami to znak zbliżającego się końca ludzkiego świata, a wraz nim i kary za powszechne zepsucie. Tak więc i Hume byłby, „sam nie wiedząc o tym, zapowiedzią, poręką, przesłańcem apokaliptycznych podrzutów historii!"24

W swych epistolarnych rozważaniach, sprowokowanych paryskimi seansami Hume’a, Krasiński z biegłością posługuje się ideami magnetyzmu. Zresztą nie czyni tego po raz pierwszy. Już listy do Delfiny Potockiej, zwłaszcza te pisane na początku lat 40., i wkomponowana w nie poezja liryczna, świadczą o gruntownym przyswojeniu przez pisarza magnetycznego dyskursu ${ }^{25}$ i to pomimo faktu, że ich autor ma poczucie niepełnej adekwatności tego języka do swych własnych koncepcji. Pragnąłby słowa idealniejszego, nieskażonego przez kontekst praktyk wielu szarlatanów, aurę sensacji, ironiczne komentarze, które towarzyszą magnetycznym pokazom. Ale taki język jeszcze nie istnieje, korzysta zatem z tego, który uznaje za ogniwo w drodze do ideału, wykazując jednocześnie krytycyzm wobec nagannych zachowań magnetyzerów, takich jak kłamstwo, iluzja, teatralizacja, nadużywanie mocy, eksploatowanie stanów chorobowych. Jeśli bowiem odrzucić tę zewnętrzną otoczkę zjawiska, to odsłania się terytorium bardzo atrakcyjnych dla romantyka idei i wyobrażeń. Świadczą o tym ponawiane w korespondencji z Potocką próby definiowania magnetyzmu, które zawsze prowadzą do jego afirmacji, pomimo wiedzy o niedostatkach. Tak więc w opinii Krasińskiego, powtórzonej za van Helmontem: „Magnetyzm jest nieznaną władzą niebieskiej natury, podobną bardzo do wpływów wywieranych przez gwiazdy i żadną przestrzeni granicą nieograniczoną. Każda istota stworzona posiada sobie właściwą ilość tej

23 Tamże, s. 414.

24 Tamże. Hume nieco inaczej pojmował swą misję - miał twierdzić, że to Bóg zezwolił mu na „te dziwne i dziwaczne po salonach obcowania z duchami”, oczywiście z duchami dobrymi, „,by ród człowieczy zwątpiały nazad do wiary w nieśmiertelność duszy przywieść”. Zob. tamże, S. 411.

25 Motywy magnetyczne w liryce Krasińskiego były przedmiotem interpretacji Macieja Szargota, który dostrzegł ich rolę w kreowaniu związku między poetą a adresatem wiersza na wzór więzi łączącej magnetyzera i medium; w efekcie sytuacja liryczna nosi znamiona magnetycznego seansu. Zob. te g o ż, Ziemia rozdziału - niebo połązenia. O liryce Zygmunta Krasińskiego, Katowice 2000 , s. $41-47$. 
niebieskiej siły"26. Gdzie indziej czytamy, że prowadzi on do połączenia „ducha ludzkiego z bożym światem nadzmysłowym i z wszechświatem zmysłowym"27, że jest on jaźni (ducha) ,potęgą zewnętrzną, narzędziem cudownym, a naturalnym jednak”28, że jest „,siłą ducha, nie schwytaną jeszcze, ale przychodzącą do siebie, która nam roztworzy państwo zmarłych"29, że jest siłą wewnętrzną ducha, który „cały, pełny działa magnetycznie, kiedy ciało działało tylko fizycznie, a dusza tylko idealnie. Im duch dzielniej wschodzić i dopełniać się będzie, tym magnetyczna siła [...] także wzrastać i dopełniać się musi. Przyszła epoka pozna ją, odtajemniczy, i wszystkie stosunki ludzkie zarazem cudownymi i naturalnymi będą" ${ }^{30}$,Magnetyzm będzie formą naturalną nadchodzącej epoki, tym aniołem stróżem z nieba zesłanym, by usuwać jej kamyki z drogi!"31

W listach do Delfiny Potockiej magnetyzm okazuje się bardzo ważnym elementem refleksji i samoświadomości antropologicznej Krasińskiego w fazie wypracowywania przezeń filozofii człowieka, powiązanej z wizją ,trzeciej epoki" ${ }^{32}$. Odwołując się do magnetycznych eksperymentów i pism, poeta gromadzi dowody przewagi ducha nad materią i ciągłego przetwarzania materii przez ducha, co uznaje za proces powszechny, gdyż jak stwierdza: „Wszędzie w Europie ludzie przez parę, galwanizm, magnetyzm, rozkładania na gazy ulatniają materię"33. Magnetyzm czyni również podstawą koncepcji ludzkiego podmiotu, syntetyzującego różne wymiary czasu, a kryjącego w sobie również wieczność ducha $^{34}$. Łączą się z tym magnetyczne egzegezy snu, pamięci, jasnowidzenia, proroctwa, ekstazy, zainteresowanie nieświadomością i nadświadomością, w których zawierają się proroctwa zarówno podniesienia materii do godności ducha ${ }^{35}$, jak i odzyskania przez człowieka rajskiej, danej Adamowi całości Ja, integralności istnienia, doskonałej harmonii ,wnętrza z zewnętrzem, ducha z ciałem, ser-

${ }^{26}$ Z. Krasińs ki, Listy do Delfiny Potockiej, dz. cyt., t. I, s. 513.

27 Tamże, t. I, s. 521.

28 Tamże, t. II, s. 140.

${ }^{29}$ Tamże, t. I, s. 518.

30 Tamże, t. II, s. 206.

${ }^{31}$ Tamże, t. I, s. 398.

${ }^{32}$ Koncepcji ,trzeciej epoki” obszerne studium poświęcił Arkadiusz B a g ła je w s ki, zob. te g o ż, Poezja „trzeciej epoki”. O twórczości Zygmunta Krasińskiego w latach 1836-1843, Lublin 2009.

${ }^{33}$ Z. Kra sińs k i, Listy do Delfiny Potockiej, dz. cyt., t. I, s. 133.

34 „Stąd to siłą wewnętrzną ducha jest magnetyzm, bo magnetyzm skupia do jedni wszędzie gdzie indziej rozrywane czasu żywioły, jak przez oko widzenia stawia w teraźniejszości żywej wszystkie przeszłości i wszystkie przyszłości. Nie ciało już ni dusza widzi przezeń lub myśli, lecz każda myśl duszy jest cieleśnie widziana, każde ciała czucie jest idealnie przemyślane, i to razem, w jednej chwili. Duch cały, pełny, działa magnetycznie, kiedy ciało działało tylko fizycznie, a dusza tylko idealnie. [...] O, gdybym był już duchem pełnym! O, gdybym rządził się magnetyczną mocą, która śpi we mnie! O, gdybym już był zamienił na służebnicę świętej, czystej i energicznej woli mojej! - nie pisałbym w tej chwili, widziałbym!” Tamże, s. 206.

${ }^{35}$ Tamże, s. 136. 
ca z rozumem" ${ }^{36}$. Z perspektywy idei magnetycznych Krasiński przeprowadza analizę władz duszy, z wolą na czele, bo - jak sądzi - magnetyzm jest wyrazem zmysłowym woli ludzkiego ducha. Wolę poeta czyni odpowiedzialną za związek myśli i serca, wiedzy i uczucia, jednocześnie świadom wynaturzeń, którym wola ulega, stając się źródłem różnorodnych zniewoleń. Wreszcie magnetyzm zajmuje uprzywilejowane miejsce także w koncepcji miłości przedkładanej Delfinie i realizowanej w ramach epistolarnego z nią kontaktu - okazuje się bardzo ważną formą miłosnej więzi: ekspresją pamięci, tęsknoty, oczekiwania, środkiem duchowego widzenia ukochanej, a nawet duchowego spotkania, niwelującego oddalenie. Jako medium miłości, „władza rozlania się na drugich, przepojenia się drugimi”, ma on według poety swój udział w tworzeniu wspólnot, poszczególnych społeczności i całej ludzkości, bo pozwala na partycypowanie, poprzez sympatię, związek serc czy solidarność duchów, w życiu całego stworzenia: „Każdy żyje s o b ą we wszystkich i wszyscy w k a żdy m żyją, ale nikt nigdy nie przepada w innych" ${ }^{37}$.

Zestawienie refleksji Krasińskiego, inspirowanej magnetyzmem w latach 40. z tą, którą formułował w roku 1857, jednoznacznie wskazuje na trwałą obecność w światopoglądzie poety niektórych magnetycznych idei i wyobrażeń. Było to z pewnością spowodowane niesłabnącą w Europie popularnością magnetyzmu, zapewne miało też źródło w różnorakich jego powinowactwach z romantycznym obrazem świata. Magnetyzm dostarczał języka, którym z większą lub mniejszą adekwatnością można było opisywać tajemnice pojedynczego człowieka, interpersonalnych relacji, natury, rzeczywistości nadprzyrodzonej, nadto dysponował spektakularnymi świadectwami potwierdzającymi doktrynę, co podnosiło jeszcze jego atrakcyjność. Kontrowersje w środowisku akademickim, które budził ów nurt medyczny i intelektualny, mogły być dla romantycznie usposobionego myśliciela argumentem potwierdzającym wyjątkową wartość tego zespołu idei, będących, jak sugerował Krasiński w cytowanym liście do Józefa Korzeniowskiego, jedną z „ran rozumu”, które obok „ran serca” nosi w sobie człowiek współczesny.

Tak więc Krasiński włączył magnetyzm w krąg swych fundamentalnych przekonań. Uczynił go integralnym elementem swej myśli antropologicznej, wyobraźni społecznej, metafizycznej i eschatologicznej. Oczywiście nie przyjmował magnetyzmu bezrefleksyjnie, bez stosownej, z punktu widzenia jego własnych celów intelektualnych, interpretacji, harmonijnie wcielającej go w system przekonań pisarza. Trzeba zarazem mieć na uwadze to, iż magnetyzm nie stanowił zjawiska jednorodnego - w wieku XIX ewoluował i rozszczepił się na szereg odmian. Można uznać, że najbliższy był Krasińskiemu magnetyzm mistyczny, z jego supranaturalizmem i przeświadczeniem o istnieniu stanów podwyższonej świa-

\footnotetext{
36 Tamże, s. 386.

37 Tamże, t. II, s. 240.
} 
domości, dających intuicyjny wgląd w przyszłość i wieczność, umożliwiających kontakt ze światem duchowym. Z równą mocą do przekonań poety przemówił magnetyzm moralny, który akcentował wychowawczą moc objawień, zdolnych skłonić człowieka do przemiany życia. Krasiński okazał się nieobojętny także na teoretyczne aspiracje niektórych przedstawicieli magnetyzmu, uprawiających swą dziedzinę z uwzględnieniem rozległych kontekstów intelektualnych: filozoficznych i naukowych ${ }^{38}$. Bo choć dziś idee magnetyzmu straciły swą sugestywność i odbierane są jako anachroniczne, należące do dziedziny wiedzy tajemnej bądź zręcznego prestidigitatorstwa, to jednak w wieku XIX mogły być postrzegane jako myśl pozostająca w głębokich relacjach dialogowych z aktualnym stanem wiedzy. Wejście w obręb refleksji magnetycznej nieuchronnie prowadziło bowiem do intelektualnej konfrontacji nie tylko z filozofią natury, ale również ze zdobyczami nauk przyrodniczych (medycyny, chemii, fizyki), a także rodzącej się psychiatrii i psychologii, które magnetyzmowi, odkrywającemu sferę ludzkiej nieświadomości, zawdzięczają szczególnie dużo. Tak rozumiany magnetyzm stał się jedną z ważkich zachęt do rozwijania przez Krasińskiego zainteresowań życiem wewnętrznym człowieka, procesami zachodzącymi w różnych obszarach ludzkiej psychiki i we wzajemnych relacjach psychiki i ciała. Psychologiczne odkrycia magnetyzmu, zwłaszcza stanu clairvoyance, jasnowidzenia, Krasiński wyzyskał, tworząc swą koncepcję poezji wizyjnej, swój wariant romantycznego profetyzmu. Posłużyły mu one również jako budulec do jego własnej koncepcji ludzkiego Ja, osoby, ducha.

A zatem kiedy słynny mediumista pojawił się w roku 1857 w Paryżu, Krasiński nie mógł go zignorować. Stawką w badaniach, które wówczas przeprowadził i w duchowej walce, którą stoczył, były jego własne, ważne, jeśli nie najważniejsze, idee antropologiczne i metafizyczne. W tej ostatniej w swym życiu intelektualnym kulminacji zabiegał o ciągłość własnego myślenia, o spójność własnego dzieła, tym samym o eschatologiczną nadzieję, o wiarę w ostateczne zwycięstwo dobra nad złem. Symbolicznie dowodził też żywotności romantyzmu, który w tej próbie zmierzenia się z fenomenem mediumisty Hume'a znalazł swe niebanalne dopełnienie, ale zarazem i przesilenie. Stanąwszy „,na brzegu nieznanej otchłani”, poeta poddał tajemnicę magnetyzmu surowej rozumowej weryfikacji, w czym niewątpliwie znajduje potwierdzenie jego trwała skłonność do poszukiwania racjonalnych uzasadnień dla tego, co irracjonalne, ale co można też kłaść na karb czasu - połowy XIX wieku i zmierzchu epoki.

${ }^{38} \mathrm{Na}$ temat wewnętrznego zróżnicowania magnetyzmu i jego związków z dziewiętnastowieczną nauką pisała Bożena Płonka-Syroka, zob. zwłaszcza: te jże, Mesmeryzm, dz. cyt. 
Agnieszka Ziołowicz.

'ON THE BRINK OF AN UNKNOWN ABYSS': ZYGMUNT KRASIŃSKI’S ANTHROPOLOGY

Su m mary

In 1857 Zygmunt Krasiński met the Scottish medium Daniel Dunglas Home. The meeting, which took place in Paris, left a lasting impression on the poet, who continued to report and interpret it in his letters. An analysis of his letters to Józef Korzeniowski, Adam Sołtan, Bronisław Trentowski, Stanisław Egbert Koźmian, and Delfina Potocka (in the 1840s) indicates that Krasiński had a profound intellectual interest in the practice and doctrine of spiritualism in all its varieties (mystical, moral, medical and philosophical). The letters also demonstrate that spiritualism was not only a persistent fascination but also an integral element of the poet's worldview at a time when he was working on his concept of the Poetry of the Third Age. It also exercised a considerable influence on his imagination and anthropology (eg. his understanding of the psychophysical parallelism, the unconscious and higher consciousness, clairvoyance, the I, the person, the spirit, and the nature of interpersonal relations). 